CHINA IN TRANSITION 
Also by David C. B. Teather

HIGHER EDUCATION IN A POST-BINARY ERA

INFORMATION TECHNOLOGY IN EDUCATIONAL

MANAGEMENT FOR SCHOOLS OF THE FUTURE (co-author)

Also by Herbert S. Yee

THE POLITICAL CULTURE OF THE MACAU CHINESE (co-author)

MACAU BEYOND 1999

A STUDY OF MACAU'S POLITICS AND PUBLIC POLICY

A TALE OF TWO CITIES: A Comparative Study of Political, Economic and Social Developments in Hong Kong and Macau

THE MODERNIZATION OF TIBETAN REGIONS: Theory, Practice and Policies

THE POLITICAL CULTURE OF CONTEMPORARY CHINESE UNIVERSITY STUDENTS 


\section{China in Transition}

\section{Issues and Policies}

Edited by

David C. B. Teather

Professor and Dean

Faculty of Social Sciences

Hong Kong Baptist University

Hong Kong

and

Herbert S. Yee

Associate Professor

Government and International Studies

Hong Kong Baptist University

Hong Kong

Consultant Editor: Jo Campling

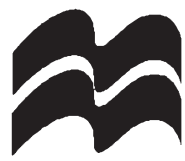


Houndmills, Basingstoke, Hampshire RG21 6XS and London

Companies and representatives throughout the world

A catalogue record for this book is available from the British Library.

ISBN 978-0-333-73134-5 ISBN 978-0-333-98382-9 (eBook) DOI $10.1057 / 9780333983829$

First published in the United States of America 1999 by

\section{ST. MARTIN'S PRESS, INC.,}

Scholarly and Reference Division,

175 Fifth Avenue, New York, N.Y. 10010

Library of Congress Cataloging-in-Publication Data

China in transition : issues and policies / edited by David C.B.

Teather, Herbert S. Yee

p. $\mathrm{cm}$.

Includes bibliographical references and index.

1. China-Politics and government-1976- 2. China-Economic conditions-1976- 3. China-Social conditions-1976- 4. China-Foreign relations-1976- I. Teather, David C. B. II. Yee, Herbert S.

DS779.26.C473524 1999

951.05-DC21

Selection, editorial matter and Introduction (C) David C. B. Teather and Herbert S. Yee 1999 Chapter 2 (C) Herbert S. Yee and Wang Jinhong 1999

Chapters 1, 3-11 @ Macmillan Press Ltd 1999

All rights reserved. No reproduction, copy or transmission of this publication may be made without written permission.

No paragraph of this publication may be reproduced, copied or transmitted save with written permission or in accordance with the provisions of the Copyright, Designs and Patents Act 1988, or under the terms of any licence permitting limited copying issued by the Copyright Licensing Agency, 90 Tottenham Court Road, London W1P 9HE.

Any person who does any unauthorised act in relation to this publication may be liable to criminal prosecution and civil claims for damages.

The authors have asserted their rights to be identified as the authors of this work in accordance with the Copyright, Designs and Patents Act 1988.

This book is printed on paper suitable for recycling and made from fully managed and sustained forest sources.

$\begin{array}{llllllllll}10 & 9 & 8 & 7 & 6 & 5 & 4 & 3 & 2 & 1\end{array}$

$\begin{array}{llllllllll}08 & 07 & 06 & 05 & 04 & 03 & 02 & 01 & 00 & 99\end{array}$ 


\section{Contents}

List of Tables and Figures

vii

Acknowledgements

ix

Notes on the Contributors

Abbreviations

xiv

Introduction

xvi

\section{Part I Political and Legal Issues}

1 New Intellectual Currents in the People's Republic of China

Werner Meissner

2 Grassroots Political Participation in Rural China

Herbert S. Yee and Wang Jinhong

3 Public Maladministration and Bureaucratic Corruption Sonny S. H. Lo

4 Legal Reform in the Quest for a Socialist Market Economy

Carlos W. H. Lo

\section{Part II Foreign Policy Issues}

5 Sino-American Relations in the Post-Cold War Era Ting Wai

6 Sovereignty Disputes across the Taiwan Straits Chen Yu Hsi

\section{Part III Economic Issues}

7 China's Regional Development Issues Li Si Ming

8 Rural Industrialization and International Trade Zhang Xiaohe 
9 The Challenge of Sustainable Development K. K. Wong

\section{Part IV Social Issues}

10 The Political Economy of Anti-Poverty in Socialist China

Luk Tak Chuen

11 The Evolution of Family Planning Policies

Siu Yat Ming

Index 


\section{List of Tables and Figures}

Tables

5.1 The US trade deficit with China

7.1 China: foreign direct investments by province, 1992-1995

8.1 Rural enterprises in the national economy, 1984-1995

8.2 Gross output value of the SOEs and the TVEs in the industrial sector, 1985-1995

8.3 Growth of TVEs' exports, 1985-1995

8.4 Export composition of rural enterprises, 1989, 1993 and 1995

9.1 Country profiles

9.2 Basic indicators

9.3 Growth and structure of production

9.4 Structure of merchandise imports and exports

9.5 Natural resources

9.6 Agriculture and food

10.1 Distribution of poor counties, 1977-1979

10.2 Provincial distribution of poor counties with per capita income lower than 50 yuan for 3 consecutive years, 1977-1979

10.3 Distribution of poor counties under the LGEDPA poverty line, 1986

10.4 National poverty lines and incidence of rural population

10.5 Provincial poverty lines and incidence of poverty, 1989

10.6 Types of poverty alleviation funds, 1989

11.1 Fertility in China, 1950-1996

11.2 Percentage distribution of birth control operations in China, 1972-1995

11.3 Reported sex ratio at birth in China, 1979-1993

\section{Figures}

7.1 China: per capita GDP by province, 1995

7.2 Coefficient of variation of provincial per capita GDP China, 1988-1995 
7.3 Distribution of foreign direct investments in China, 1992-1995

8.1 The change in China's exports pattern, 1980-1995 159

8.2 Composition of manufacturing exports by sectors 


\section{Acknowledgements}

Several years before the return of Hong Kong to China, the Civil Service Training and Development Institute of the Hong Kong Government contracted the Hong Kong Baptist University to provide two short courses on understanding contemporary China. Since that time six of these courses have been offered each year, with each course attracting over a hundred civil servants of all ages and from all branches of government. The editors of this book organised these courses, and most of the authors of the chapters contributed the lectures.

Hong Kong was then, and is still, a unique vantage point from which to view China. Apart from the villagers of the New Territories, most Hongkongers or their immediate forebears migrated here from other parts of China - many from neighbouring Guangdong Province, some from much further afield. Since the open-door policy of 1978, family ties and business connections have been re-established, so information about China gleaned from the news media is complemented by personal experience. Academics from Hong Kong are frequent visitors to other parts of China.

Yet Hong Kong, the most modern of Chinese cities, looks also to the West. Its universities are staffed by academics who have studied and worked overseas, and who would be equally at home in the universities of Chicago, London, Toronto or Sydney. It is this combination of, on the one hand, intimate knowledge of China and, on the other hand, familiarity with Western ways, that enables the contributors to this volume to communicate so insightfully and effectively to English-language readers.

The editors would like to thank all those who have contributed to this book. In addition to the authors of the chapters themselves, we thank those other academics who participated in two workshops, 15 months apart, in which drafts of all the chapters were presented and critiqued. Among these participants were Professor Sung Yun Wing of the Chinese University of Hong Kong; Professor Leonard Chu, Dr Larry Chow, Professor Ma Hing Keung, Dr Danny Paau, Professor Herbert Tsang, Mr To Yui Ming and Mr Woo Tun Oy of Hong Kong Baptist University; and Dr Guo Zhenglin of Zhongshan University.

Many people helped with the organisation of these workshops, and with the wordprocessing of the individual chapters. Ms Ada To, 
Secretary of the China Studies Programme of Hong Kong Baptist University, contributed throughout, and not least in the preparation of the final typescript. She was assisted by colleagues and students from the Faculty of Social Sciences office.

Special thanks are due also to Jo Campling who, following a visit to Hong Kong Baptist University, encouraged the editors to prepare the typescript for publication and who, together with Annabelle Buckley and colleagues at Macmillan, provided both generous professional advice and practical help in transforming the typescript into the published book.

We hope that the publication of this book will help towards real understanding of contemporary China in the English-speaking world.

DAvid C. B. TeATHER Herbert S. YeE 


\section{Notes on the Contributors}

CHEN Yu Hsi is Associate Professor of Journalism, Hong Kong Baptist University. He was a journalist in Taiwan and the US for more than ten years. From 1982 to 1987 he was Deputy Chief Editor and Chief Editorialist of Centre Daily News in New York City. He writes extensively on political and socioeconomic issues relating to Greater China. He is the author of Dependent Development and Its Sociopolitical Consequences: A Case Study of Taiwan and Nation Divided: Selected Essays and Papers on Greater-China Political Economy.

Luk Tak CHUEN is Lecturer in Sociology, Hong Kong Baptist University. His research interests include organizations, stratification, work and industry, Chinese society, and labour studies. He has contributed book chapters and articles to scholarly journals.

LI Si Ming is Professor of Geography, Hong Kong Baptist University. His research interests include urban studies and housing, both economic and social aspects. He has contributed book chapters to edited books, and articles to a number of international journals. He has recently edited or co-edited three books entitled Perspectives on the Regional Economy of China, The Other Hong Kong Report and Social Development in China: Analysis of Hong Kong Scholars.

Carlos W. H. LO is Associate Professor in the Department of Management at the Hong Kong Polytechnic University. His area of interests are in Chinese law and government, environmental management, and public sector management. He has recently published a book entitled China's Legal Awakening: Legal Theory and Criminal Justice in Deng's Era. He has contributed articles to Environmental Management, Public Administration \& Development, and Journal of Contemporary China.

Sonny S. H. LO is Lecturer in Politics, University of Hong Kong. His research interests include the politics of China, Hong Kong and Macau. $\mathrm{He}$ is the author of two recently published books entitled Political Development in Macau and The Politics of Democratization in Hong Kong. He has contributed articles to China Quarterly, Asian Survey, Journal of Contemporary China, Pacific Affairs and other scholarly journals. 
Werner MEISSNER is Professor of Government and International Studies, Hong Kong Baptist University. A specialist in Chinese political thought he is the author of Philosophy and Politics in China: The Controversy on Dialectical Materialism in the 1930s. His recent publications include Western Philosophy in the People's Republic of China, 1987-1992: A Bibliography and Western Political Science in the People's Republic of China, 1987-1992: A Bibliography.

SIU Yat Ming is Associate Professor of Sociology, Hong Kong Baptist University. His research interests include population studies and Chinese society. He has contributed a chapter to China Review 1993 and articles to scholarly journals. He has edited (with Li Si Ming and Mok Tai-kee) a book entitled Social Development in China: Analysis of Hong Kong Scholars.

David C. B. TEATHER obtained batchelor and doctoral degrees at University College London. He subsequently held academic appointments at the Universities of London, Liverpool, Otago and New England, before taking up the post of Professor and Dean of the Faculty of Social Sciences at Hong Kong Baptist University. His recent books include Higher Education in a Post-Binary Era and (with Alex Fung and Others) Information Technology in Educational Management for Schools of the Future.

TING Wai is Associate Professor of Government and International Studies, Hong Kong Baptist University. His research includes the domestic politics and foreign policies of China, and China-Hong Kong relations. His latest publications include a monograph entitled The External Relations and International Status of Hong Kong.

WANG Jinhong is Lecturer in Politics, South China Normal University, Guangzhou. His research interests include the politics of Chinese peasants and national minorities. He is the co-author of a book entitled Chinese Public Policies: Theories and Practices. He has contributed articles to scholarly journals published in mainland China.

K. K. WONG is Lecturer in Geography, Hong Kong Baptist University. His research interests include man-environment interaction, environmental policy, sustainable development, environmental and landscape perceptions, housing satisfaction and environmental education. He publishes widely in international journals and in edited books.

Herbert S. YEE is Associate Professor in Government and International Studies at the Hong Kong Baptist University. He has authored or edited 
several books on Chinese politics (all in Chinese). He has contributed book chapters to edited books and articles to international journals.

ZHANG Xiaohe is Lecturer in Economics, Hong Kong Baptist University. His research interests include Chinese political economy, international trade, and foreign investment in China. His recent publications appear in Journal of Development Studies, Industry and Development and China Economic Review. 


\section{Abbreviations}

APEC

APL

ASEAN

BOC

CASS

CCP

CDIC

CMC

CPPCC

DPP

EU

FDI

FFE

FIE

FRG

GATT

GDP

GDR

GIOV

HKSAR

ICAC

IMF

KMT

LDC

LGEDPA

MDC

MFN

MTCR

NCNA

NEPA

NPC

NPT

PADO

PAP
Asia Pacific Economic Cooperation

Administrative Procedure Law

Association of South East Asian Nations

Bank of China

Chinese Academy of Social Sciences

Chinese Communist Party

Central Discipline Inspection Commission

Central Military Commission

Chinese People's Political Consultative Conference

Democratic Progressive Party (Taiwan)

European Union

Foreign direct investment

Foreign funded enterprise

Foreign invested enterprise

Federal Republic of Germany

General Agreement on Tariffs and Trade

Gross domestic product

German Democratic Republic

Gross industrial output value

Hong Kong Special Administrative Region

Independent Commission Against Corruption

(Hong Kong)

International Monetary Fund

Kuomintang

Less developed country

Leading Group for the Economic Development of Poor

Area

More developed country

Most favoured nation

Missile Technology Control Regime

New China (Xinhua) News Agency

National Environmental Protection Agency

National People's Congress

Nuclear Non-Proliferation Treaty

Poor Area Development Office

People's Armed Police 
PLA People's Liberation Army

PPP

Purchasing power parity

PRC

People's Republic of China

PSB

Public Security Bureau

RMB

Renminbi (Chinese currency)

RMRB

Renmin ribao (People's Daily)

ROC

Republic of China

SEZ

Special economic zone

SIPC

SOE

Shenzhen Intermediate People's Court

State-owned enterprise

TIM

TVE

UK

Taiwan independent movement

Township and village enterprise

UNDP

United Kingdom

US

United Nations Development Programme

USSR

United States

VAT

Union of Soviet Socialist Republics

WCED

WMD

WTO

Value-added tax

World Commission on Environment and Development

Weapons of mass destruction

ZGTJNJ

World Trade Organization

Zhongguo tongji nianjian (Statistical Yearbook of China) 


\section{Introduction}

The last two decades of the twentieth century are the turning point in contemporary Chinese history. After two decades of reform and the open door policy, China has accomplished achievements on all fronts. To many people China is a rising world power and may even overtake the United States in GNP by or before the middle of the twenty-first century. ${ }^{1}$ Indeed, according to the Purchasing Power Parity (PPP) calculations, China has already become the world's second or third largest economy. Yet accompanying the process of reform and the open door policy many problems became apparent. Many are related to the policy formulation and implementation process, but a significant proportion of problems are institutional, caused by inherent contradictions within the Chinese political and economic systems. The objective of this book is selectively to analyse some of the problems and issues confronted by the Chinese leaders. We believe that the policy issues selected in this volume are quite representative of the current political, economic, and social situations in China.

From the perspective of long-term political development, the political changes of the last two decades of this century are crucial. In order to rectify the radical leftist mistakes of the 'Cultural Revolution' (1966-76), Deng Xiaoping, after he came to power in 1978, adopted a pragmatic, unorthodox approach towards politics. Deng downgraded the importance of ideology and refused to hold any mass political campaigns or to undertake class struggle. Deng's stress on economic development has no doubt contributed to the rapid economic and social development in the last two decades, yet his neglect of ideology had contributed to the 'confidence crisis' or 'authority crisis' of the Chinese Communist Party (CCP). The prestige and authority of the CCP reached an all-time low in the 1980s among the Chinese populace. The legitimacy of Communist rule was at stake. Deng and his supporters included the 'Four Cardinal Principles' in the 1982 constitution, the core of which was to ensure the dictatorship of the CCP. The Dengists were also actively involved in searching for a new ideology or model of government to replace the increasingly unpopular orthodox Marxist-Leninist-Maoist model. At different times in the 1980s, the European model of 'social democracy' and a Singaporean 
model of 'neo-authoritarian' government were proposed and seriously discussed among academics and officials. ${ }^{2}$ Yet the disintegration of the former Soviet Union and the downfall of Zhao Ziyang, the former CCP general secretary, whose associates had proposed the notion of 'neo-authoritarianism', abruptly ended the discourse in searching for an appropriate political model for the regime. The post-Deng leadership merely holds on to the fading shell of socialism.

The perennial crisis facing the Communist regime is leadership succession. China does not yet have an institutionalized system for leadership succession. The final outcome is often the result of a power struggle or political compromises among different Party factions. After the death in 1997 of Deng Xiaoping, China's Paramount Leader, Jiang Zemin, the Party Secretary and the Chairman of the Central Military Committee, gradually assured his grip of the military and Party. Jiang Zemin became more assertive after ousting former Beijing mayor Chen Xitong in a corruption scandal. Jiang foced Qiao Shi, Chairman of the National People's Congress and Jiang's arch rival in the power struggle to succeed Deng, to an early 'retirement' in the First Plenum of the Fifteenth CCP's Central Committee, held in September 1997. Then some high-level officials and cadres in Beijing publicly referred to Jiang as 'Chairman' (Zhuxi) or 'Leader' (Lingxiu) without the surname, which was reminiscent of the 'Cultural Revolution' era when Mao Zedong was indisputably regarded as the 'Chairman' or 'Leader' of China. However, unlike his predecessors Mao and Deng, Jiang does not have charismatic appeal and is more likely to rely on collective leadership to take China into the twentyfirst century.

China has enjoyed an unprecedented period of economic growth since the early 1980s. Inflationary pressures sparked by an overheated economy in the early 1990 s are apparently under control. The Chinese economy has achieved a 'soft-landing' after policy measures taken by the central government to control money supply and to restrain the further development of over-expanded infrastructures. However, many problems remain to be tackled such as, inter alia, income disparities between the coastal regions and the hinterland provinces as well as between the cities and the rural areas, the perennial problems of the state-owned enterprises, and the issue of environmental protection. Rapid and sustained economic growth has also brought enormous social changes in Chinese cities and villages. The new wealthy have enjoyed high social status and played an increasingly important role in local politics. Yet poverty in the less developed 
regions and the issue of population control will continue to haunt the Chinese leaders who put top policy priority on maintaining political and social stability.

China's foreign policy orientation, on the other hand, underwent substantial change in the 1990s. In the new post-Cold War era, China is no longer confronted with military threats on its borders. Indeed, China enjoys an unprecedented peaceful global and regional environment. Beijing has made friends with all countries, regardless of ideology, which are willing to terminate their diplomatic relations with Taipei. Hong Kong became part of China in 1997 and Macau followed suit in 1999. Taiwan is the only Chinese territory outside Beijing's control. Understandably, the Taiwan issue remains the major concern of the Chinese leaders. The other important foreign policy issue is China's relations with the United States. After the collapse of the former Soviet Union, the United States became the only military superpower in global politics. Washington's policy strategies in the Asian-Pacific region, particularly its attitudes towards the disputes in the Taiwan Straits and the South China Sea, are closely watched by Beijing. Jiang Zemin's official visit to the United States and his summit meeting with President Clinton in October 1997 was hailed as an important breakthrough in Sino-American relations. Beijing has established a 'strategic partnership' with Washington, Moscow, London, and Paris. A more assertive China will certainly play an increasingly important role in regional and global politics.

This book comprises four parts, addressing respectively politicolegal, foreign policy, economic and social issues. In Chapter 1, Werner Meissner examines the intellectual developments in searching for an appropriate political ideology for China. Since the middle of the last century, the intellectual history of China has been characterised by the oscillation between rejection and acceptance of Western thought. Meissner describes the four periods of this development until the late 1970s and mentions briefly the main currents that developed during that time. Since the beginning of the 1980s the policy of the Four Modernisations (agriculture, industry, defence, and science and technology) has triggered off a completely unexpected new move to adopt Western thought. Before the backdrop of the decline of Maoism, five intellectual developments can be observed: (1) the renaissance of Western political science; (2) the renaissance of non-Marxist philosophy; (3) the revival of Western political liberalism; (4) Neo-authoritarianism; and, in particular, (5) the renaissance of Chinese traditional philosophy. 
The chapter provides data regarding the translation of books and articles on Western political science and Western philosophy since the 1980s into Chinese. Between 1987 and 1992 about 500 books and articles on Western domestic politics were translated from Western languages; during the same period about 3500 translations of works by Western authors and by Chinese authors on Western philosophy were published. The chapter concludes by pointing out the possible emergence of a 'National-Confucianism' in China. According to the author, the rehabilitation of Confucianism in recent years has served a dual purpose: (1) Confucianism means order and obedience to one's superior, devotion to the State, and puts the interests of the group above the interests of the individual and thus helps to promote the desperately needed social order and stability; and (2) Confucianism as an ideology could provide the Chinese people with some sort of national identity. In short, National-Confucianism could serve as a bulwark against the ideological incursions from the West.

In the next chapter Herbert Yee and Wang Jinhong examine grassroots political participation in rural China. The authors describe the socio-economic changes that have been taking place in China's villages since the late 1970 s and that have caused the rising aspirations for political participation among the peasants. Defining political participation as an attempt by citizens to influence government policies, Yee and Wang analyse the different channels and methods of influence as well as the motivations and efficacies of political participation in China's villages. Unlike the years of the communes and brigades, when the peasants were mobilized during the mass political campaigns, political participation in the 1980s and 1990s was largely spontaneous. Rapid economic growth brought a new middle, capitalist class and a phenomenal rise of traditional clan and kinship associations in the villages. Yee and Wang argue that the intriguing collaborations between the new wealth and the clan and kinship organizations have played a constructive role in developing the rural economy and maintaining social order and stability in the villages. In the long-run, however, the rise of 'unofficial' organizations may threaten the legitimacy of the official organizations of Party and government.

In Chapter 3, Sonny Lo investigates the problems of corruption and public maladministration and their remedies in China. Lo explains the relationship between corruption and maladministration. According to Lo, there are three major approaches to tackling public maladministration, including various characteristics of poor government, such as 
abuse of power, mismanagement and bureaucratic corruption. Lo argues that, in the Maoist era, China adopted a political approach to tackling public maladministration. This Maoist approach was an ideological one, focusing on the use of study groups and political campaigns. The unintended consequence of ideologization in Maoist China was that there developed a kind of public service ideology, which was shaped by socialism and which emphasized the necessity of officials to serve the public. Deng Xiaoping, Mao's successor, deemphasized the role of ideology in tackling maladministration. The Dengist approach to public maladministration tends to focus on managerial and legal aspects. Managerially, civil service reform has been implemented. Legally, administrative laws have been enacted to check the power of 'street-level' bureaucrats. However, managerial and legal reforms in Deng's China encounter political obstacles. The alliance between the capitalists and bureaucrats, the unclear boundary between the private and public sectors, the weaknesses of the anticorruption organ (Central Discipline Inspection Committee), and the opposition of elites constitute the stumbling blocks for managerial and legal remedies for public maladministration. Ultimately, Lo argues, a third approach that includes political reforms directed towards making the legislature (National People's Congress) more assertive, enhancing the channels for citizen participation, allowing the media more autonomy to criticize the government, and perhaps reactivating part of the Maoist ideological approach, could best tackle the problem of public maladministration in the long run.

In the last chapter of Part I, Carlos Lo examines the legal reform in socialist China since the June-Fourth 1989 Tiananmen Square Incident. The author argues that, despite the tragic outcome of the June-Fourth Incident and the ensuing purge which threatened the very existence of the socialist legal system, once the political fever had subsided and the economic reform had been revived, China managed to return to the track heading for a legal society. This chapter examines the legislative activities, the development of legal institutions, the promotion of the nation's legal awareness, and law enforcement in the post-Tiananmen crisis China. It indicates that China has recorded some significant advances in legislation, legal institutional building and raising the legal awareness of the population. Most of the legislative endeavours have centred on developing a system of economic law for introducing and operating a socialist market economy. Other major areas of legislation include criminal justice, public and social administration, and institutional reform. Institution building has a wide coverage, with 
efforts to tighten Party control over the judicial system, build a clean and honest image, upgrade the quality of legal personnel, strengthen judicial structures, improve logistic support and institutionalize the lawyers' system. The nation-wide campaign to develop a national legal culture has been intensified with the objective of educating both cadres and the public to manage their activities by means of the law. In the administration of justice, Lo shows that the growth of judicial capacity has lagged behind the actual demand for law implementation. This affects the effectiveness of the legal system. In criminal justice, little success has been recorded as both corruption and criminal activities show no sign of being checked. In the non-criminal sector, the judicial organs have been active in settling administrative, civil and economic disputes.

Chapters in Part II address foreign policy issues. Ting Wai critically examines how China's perception of the United States' role and the latter's perception of the Chinese role in the post-Cold War world order affected the two countries' respective evaluations of SinoAmerician relations. To what extent are these perceptions influential in the two countries' foreign policy decision-making processes? What kinds of structural constraints of the new international political order are imposed on the future development of Sino-American relations? China's further reforms are in the interests of the United States, which is seeking a comprehensive and constructive engagement with China. The paradox is: China would like to integrate into the global economic system, but she declines to become part of the order dictated by the US. An increasingly prosperous China, facing the challenges and pressure from the West, is becoming more and more self-assertive and nationalistic. Ting argues that difficulties will persist, while limited cooperation may also be possible in the future of Sino-American relations. Issues in the domestic political ecology of the two countries, including the political succession in China, and public opinion in US regarding a democratic Taiwan and the JuneFourth bloodshed in China, could increase uncertainties that affect the policy imperatives of the two governments.

Chen Yu Hsi examines the disputes across the Taiwan straits. Strictly speaking, or at least from the standpoint of Beijing, the Taiwan issue is a matter of domestic politics. Chen provides a discourse on how the disputes over national sovereignty between mainland China and Taiwan have evolved, and seeks to identify the nature and root causes of the disputes in different phases of this evolution in the light of both domestic and international politics. Chen argues that, 
despite the changes in its mainland policy and political rhetoric, the basic position of the Taiwan government on the sovereignty issue cannot be understood in terms of a dichotomy between reunification and Taiwan independence; the Taiwan government merely wants to maintain the status quo and intends to preserve Taiwan as a distinct political entity separate from the communist-oriented mainland polity. He also points out that the Taiwan government has, since the beginning of the 1990s, shifted its mainland policy towards the 'two-China' model, not only out of a need to improve its relations with the mainland but, more importantly, to lay a legal foundation for democratic political reforms.

Chen argues that the only way Beijing and Taipei can resolve their sovereignty disputes peacefully is to revert to the 'two-China' model. The successful economic development and democratic reforms in Taiwan have enhanced the legitimacy of its political system and the awareness and identity of the 'Republic of China on Taiwan' as a distinct sovereign state, to the extent that both the people and government of Taiwan would refuse to consider peaceful reunification unless Beijing accepts Taipei as a legal government. The author suggests that Beijing should accept the concept of 'sovereignty sharing' and the 'one nation, two political entities' model as proposed by Taipei. He stresses the importance of making mutual political concessions and compromises in the long-term interests of the Chinese nation.

Chapters in Part III address the economic issues. Li Si Ming examines the issue of regional development. $\mathrm{Li}$ argues that in China there has been a felt need for rapid industrialization ever since the late nineteenth century. Alongside this and central to the communist ideology, however, are the emphases on egalitarianism and equity. China's massive size, varied physical geography and 5000 years of history suggest that enormous differences exist between regions. An integral part of the egalitarianism agenda is the elimination of spatial disparity. Industrialization, especially the development of capitalintensive 'basic industries', however, requires a concentration of resources in selected urban centres. The spatial reallocation exercise often results in a development strategy that favours not only the urban areas at the expense of the vast rural hinterlands but also regions that are already endowed with resources, especially in terms of industrial and human capital. Adding to the quest for industrialization and the egalitarianism ideology is the concern for national security and integration. China is a country with many 'nationalities'. Some of these, notably the Mongols, Uygurs and Tibetans, have attempted secession. 
There is therefore a need, Li argues, to design specific policies that can enhance the cohesiveness of the minority groups, including the transfer of resources from the more developed regions populated by Han Chinese to the frontier regions with large concentrations of minority population.

Li points out that the history of regional development in the PRC is one full of self contradictions and ironies, reflecting competing objectives. At times, as was the case during the Cultural Revolution, it appeared that egalitarian considerations had taken precedence over the drive for industrialization; however, the reality was that, through such means as the household registration system and the 'scissors difference' 3 in pricing, resources continued to be siphoned from the rural areas to the urban centres, and from the lagging interior of the country to the more prosperous coastal provinces. At other times, such as during the late 1980 s, there was an obvious policy bias favouring the coastal region; however, the greater autonomy given to the provinces allowed them to exert a greater influence over the flow of resources over space, thus inhibiting the geographical transfer of value. The end result was a rapid decline in the degree of regional income disparity amidst a re-orientation of the national economy towards the outside world. The fiscal reform of 1993 was meant to end the particularistic treatment of individual provinces and to bring about a more equitable distribution of resources over space. Yet the massive inflow of foreign capital since Deng's southern tour of early 1992 has worsened the degree of spatial disparity.

Zhang Xiaohe examines the development of the township and village enterprises (TVEs) and their contributions to China's export growth. The growth of China's rural enterprises had been very impressive in the 1980s and early 1990s. The total output of the township and village enterprises grew at an average annual rate of 30 per cent from 1980 to 1995. In 1994, these enterprises produced about 47 per cent of the national total industrial product and provided employment for 120 million people. The growth of output of the township and village enterprises and their capability to provide employment far exceed those of the state owned enterprises (SOEs). Along with the foreign funded enterprises (FFEs), TVEs have become a main component of the so-called non-state sector. One distinguishing feature of the township and village enterprises is the significant role they played in foreign trade. In 1994, there were more than 130000 outward-looking TVEs, of which more than 320 firms have been vested with the right of direct international transactions. The export 
value of the TVEs reached US\$40 billion in 1994, accounting for more than one-third of the national total. The participation of these enterprises in international trade greatly contributed to China's export growth.

Two questions are raised by Zhang. First, is the emergence of rural industrial exports a main source of the rapid growth of China's international trade? Second, how and to what extent has the development of TVEs' exports changed China's export composition? Applying standard international trade and development theory, Zhang provides some different insights on these issues, in contrast to previous studies. He attributes the rapid growth of China's labour-intensive exports and radical changes in its export composition to the nature of China's partial economic liberalization in general, and to the features of labour-intensive rural enterprises in particular.

Kenneth Wong examines the tensions between economic growth and environmental protection in China. Beijing incorporated the concept of sustainable development, which demands raising the standard of living of people without incurring uncompensated costs to future generations, in the Ninth Five-Year Plan (1996-2000) and the Long-term Goals for the Year 2010. On paper at least, the present regime seems very eager to pursue a policy of sustainable development. However, Wong argues, China's current economic development strategy is still one that takes the increase of gross national product or per capita income as its ultimate goal, a strategy that places its emphasis on quickening the pace of industrialization. Such growth has put even greater pressure on the already meagre resources and fragile environment. Moreover, the current regime regards economic growth as the manifestation of national strength and wealth, and the symbol of national prosperity and national pride. China's dilemma is that it has a huge population but a far smaller slice of the world's resources. For instance, with one fifth of the world's population, China has only 7 per cent of its fresh water and cropland, 3 per cent of its forests, and 2 per cent of its oil. According to the current trend of China's economic development, it can no longer rely solely on its own resources to sustain its economic growth. It will inevitably impose pressure on world resources. Wong comments on some of the sustainable development programmes put forward by the Chinese government in recent years. He argues that if China does not want to be trapped into the unreconcilable conflict between economic growth and environmental protection, it must pursue a policy of steady, sustainable and balanced development. 
Part IV addresses the social issues. Luk Tak Chuen examines rural poverty and the Chinese Government's poverty alleviation policies. The Chinese Government pronounced a mission in 1994 to raise the living standards of the poorest 65 million of the population to acceptable levels by the year 2000. With the National Seven Year Poverty Eradication Programme, a series of poverty alleviation policies had been formulated to mobilize the various bureaucracies as well as the public to participate in this campaign. Luk, however, argues that the effectiveness of these anti-poverty programmes is severely handicapped by bureaucratic decentralization, bureaucratism, and the onslaught of the market economy in Chinese state socialism. The chapter explores how politics and economics enter into the process of poverty definition, policy formulation and implementation of poverty alleviation programmes, and thus affect the effectiveness of these antipoverty efforts.

According to Luk, the obscure and unsystematic official poverty line prevents the Chinese Government from obtaining accurate measures of poverty. The Chinese Government does not make clear the rationale behind the standard of poverty definition. The standard of the official poverty line that China adopts is far below the international convention of absolute poverty; the number of the poor is severely underestimated. The official poverty line even fails to take inflation into account and cannot reflect change in the size of the poor population amidst the raging inflation of recent years. The obscure and unsystematic definition of poverty allows the central government and related bureaucracies to manipulate the numbers of the poor for administrative as well as political purposes. Amidst market reform and bureaucratic decentralization, the poverty alleviation programmes do not regulate the regional inequalities, but instead strengthen the disparities by administrative intervention. Loans and grants are channeled to industries rather than to agriculture, to better-off regions and better-off households rather than to the needy households and regions. Poverty alleviation programmes leave the poorest peasant households and regions untouched and even worse off amidst the inflationary pressures of market reform. Moreover, bureaucratic politics hinders the effectiveness of poverty alleviation programmes. The large numbers of ministries, mass organizations and various levels of bureaucracies taking part do not constitute a concerted campaign against poverty. The multiplicity of bureaucracies involved fragment authority in the formulation and implementation of poverty alleviation programmes. 
Siu Yat Ming examines the issue of China's birth planning policies. The population of China was estimated to be 542 million at the founding of the People's Republic in 1949; that figure was more than doubled when the fourth census was taken in 1990 with the count then recorded at 1134 million. The number passed the 1.2 billion mark in 1995. This figure, though large in size, was smaller than that expected by many demographers and China observers. The major reason for this low figure was the reduction in the rate of natural increase as a result of the declining birth rate, despite the increase in the number of women at their prime child-bearing age. The major cause of China's fertility decline can be attributed to the continuing success of the state-operated birth planning programme. Since the implementation of the national birth planning programme in 1973, about 300 million births had been averted by 1995 . Siu analyses the evolution of China's birth planning policies since the $1950 \mathrm{~s}$ in the political and social context. It was not until the early 1970 s that a consensus on the population problem was reached in the Chinese government. A nationwide birth planning programme was then implemented, leading to an unprecedented rapid decline in fertility. Despite the changing economic conditions and declining fertility, the present tightened policies of birth control are not likely to change.

The author points out, however, that there are two major demographic consequences accompanying the fertility decline. One is the rapid ageing of the population, which is an unavoidable consequence of rapid fertility decline. This problem is particularly acute in China because the speed of the fertility decline is much faster than that experienced by the more developed countries, and China's economy is not sufficiently developed to provide old-age security to all needy persons. The other demographic consequence is the increasing imbalance in the sex ratio in young children, especially in babies, starting from the 1980s. There were numerous reports of female infanticides. Pre-natal sex determination and sex-selective abortion have been widely practiced since the mid-1980s. The underlying reason for this change in the male/female ratio in favour of males is a limit on the number of children one can have in a culture in which sons have been preferred.

DAVID C. B. TEATHER HERBERT S. YeE 


\section{Notes and References}

1. See, for example, William H. Overholt, The Rise of China: How Economic Reform is Creating a New Superpower (New York \& London: W. W. Norton, 1993); and Laurence J. Brahm, China is No. 1: The New Superpower Takes Centre Stage (Singapore: Butterworth-Heinemann Asia, 1996).

2. Yan Sun, The Chinese Reassessment of Socialism, 1976-1992 (Princeton, New Jersey: Princeton University Press, 1995).

3. Before economic reforms, the Chinese Government treated the agricultural sector as a source of surplus products for industrialization. The price of agricultural products was set at a low level while the price of industrial products was set at a high level; this is called the 'scissors difference'. 